\title{
Ring Dosage Form
}

National Cancer Institute

\section{Source}

National Cancer Institute. Ring Dosage Form. NCI Thesaurus. Code C60988.

A solid composed active and/or inert ing redient(s) of in the shape of a hoop. 